\title{
Endoscopic necrosectomy using electric conductivity: anchoring the snare tip into a groove made with Endocut may improve necrosis grasping
}

Around $20-30 \%$ of all acute cases of pancreatitis are necrotizing, further marred by a $10-20 \%$ mortality rate [1]. Walledoff pancreatic fluid or necrotic collections can lead to complications such as compression or secondary infection. In these cases, a step-up approach is recommended [2,3] instead of open surgery, first with decompression by cystogastrostomy for fluid collection, followed by an endoscopic necrosectomy if solid components remain in the drained collection. However, endoscopic necrosectomy is quite a frustrating procedure because only small amounts of necrotic tissue are removed with each pass. Indeed, there is no specific tool and the handle slides above the necrosis. Evaluation of the recent approaches with the Endorotor to remove the necrosis are still ongoing, but this technique is also time-consuming [4].

We report the case of a 67-year-old woman, hospitalized for biliary Balthazar E acute pancreatitis with several necrotic collections. At day 17, a secondary infection developed and an AXIOS stent was used to drain the collection.

However, at day 23, sepsis was still not controlled, and a computed tomography (CT) scan revealed remaining solid components in the collection. During the necrosectomy, we tried to improve grasping by making grooves in the necrosis with the tip of the snare. Surprisingly, despite the necrotic tissue, conductivity was maintained using Endocut electric current (Erbe, Tuebingen, Germany), and the tip of the snare could be used to cut and dissect the necrosis ( Fig. 1, - Video 1). Thanks to this ability, we managed to cut the necrosis into large square pieces, facilitating snare placement in the groove in order to grasp larger pieces without sliding ( Fig.2).
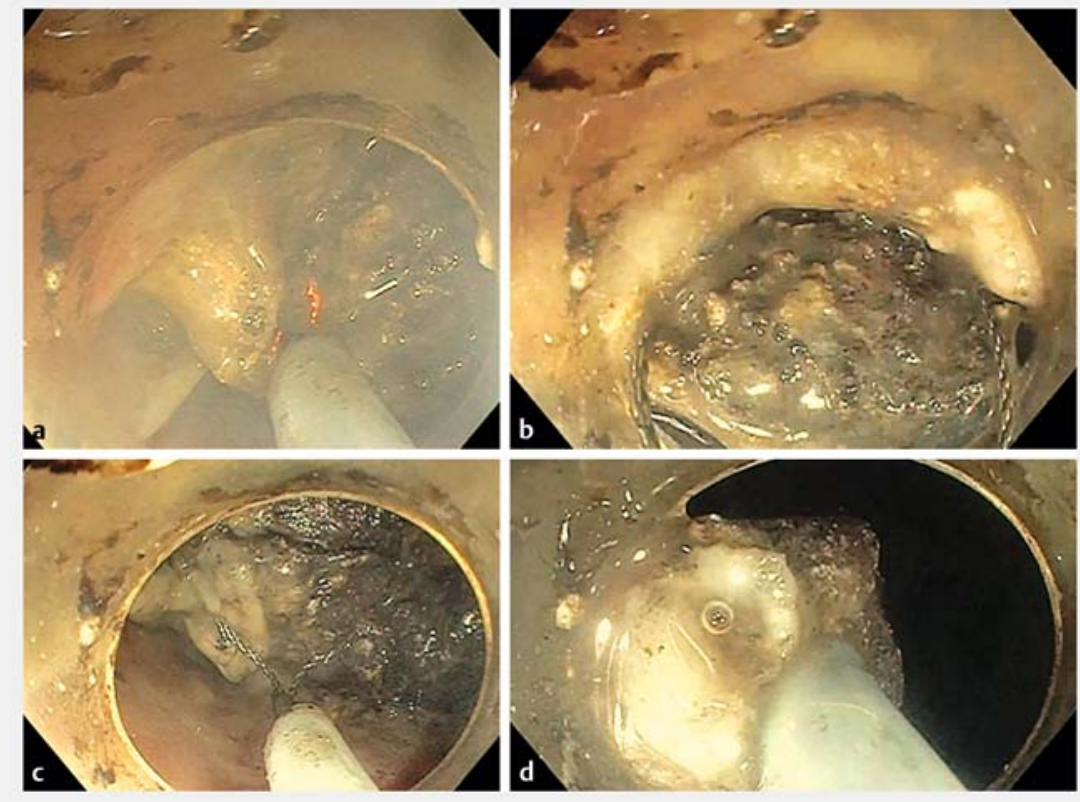

- Fig. 1 Aspect of necrosectomy procedure. a Groove incision with the tip of the snare. b Snare placement into the groove. c Snare grasping. d Removal of the piece of necrosis.
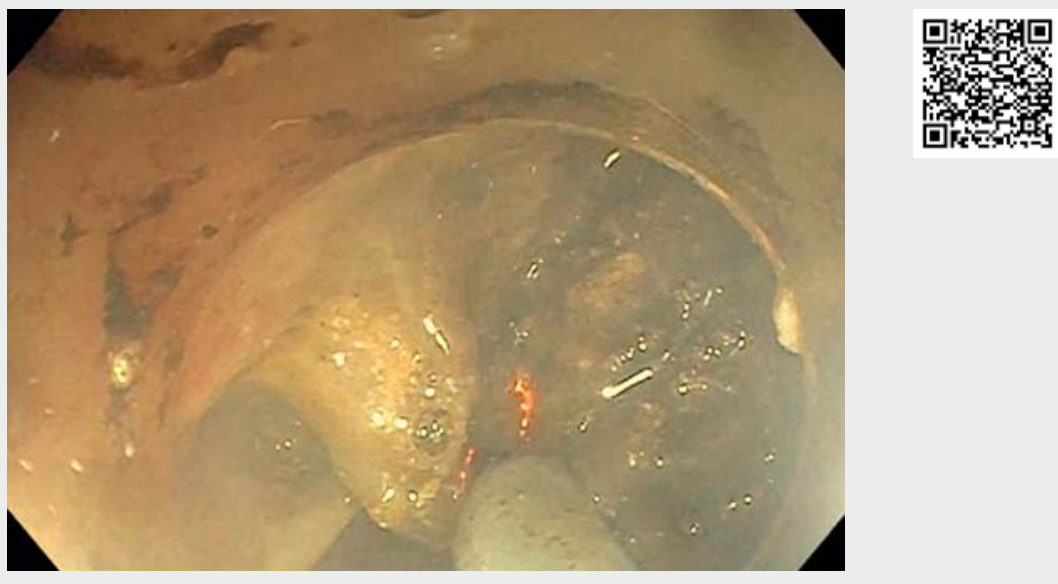

$\nabla$ Video 1 Endoscopic necrosectomy using conductivity: anchoring the snare tip into a groove made with electric current may improve necrosis grasping. 

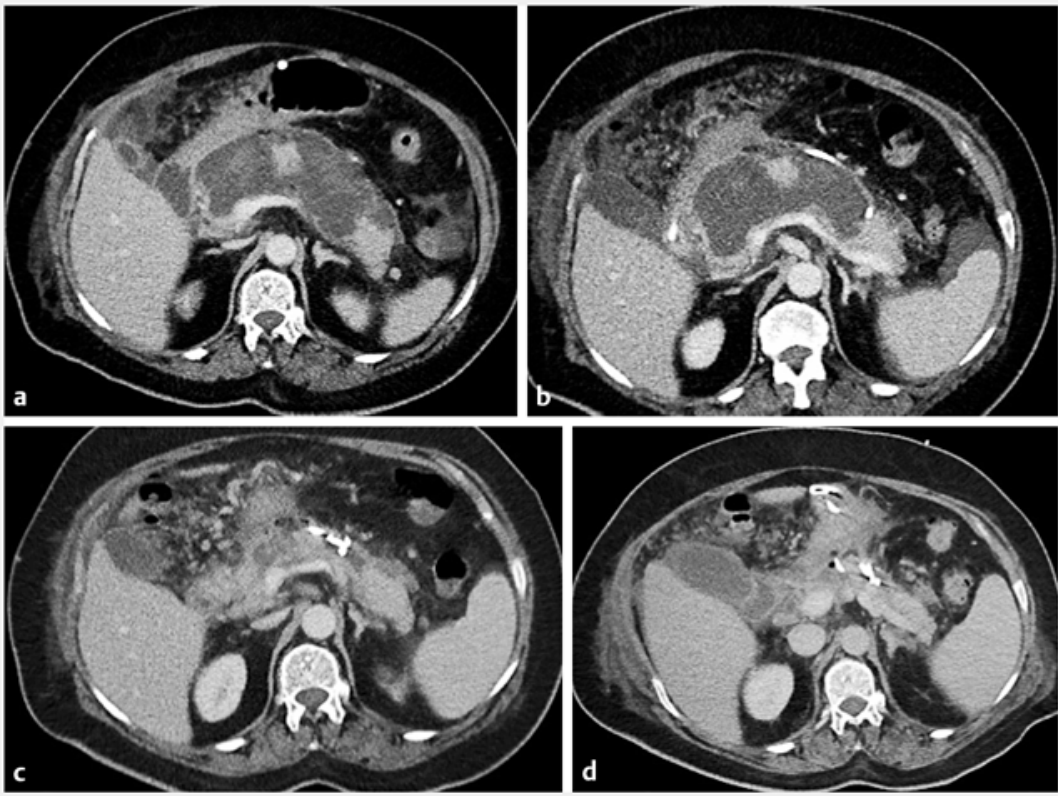

Fig. 2 Computed tomography (CT) scan of the pancreatic necrosis before and after necrosectomy. a CT scan with large necrotic collection before any drainage. b CT scan after AXIOS drainage. c CT scan immediately after necrosectomy. $\mathbf{d}$ CT scan after 1 month and double pigtail stent replacement of the diabolo stent.

To the best of our knowledge, there is no really efficient method for endoscopic necrosectomy. Necrosis conductivity can be used to create grooves to facilitate snare grasping to remove larger pieces. A comparison with the Endorotor strategy is mandatory to choose the safer and more efficient strategy.

Endoscopy_UCTN_Code_TTT_1AS_2AG

\section{Competing interests}

The authors declare that they have no conflict of interest.
The authors

Alexiane Delmeule ${ }^{1}$, Jérémie Jacques ${ }^{2}$, Thomas Lambin ${ }^{1}$, Frédéric Moll' ${ }^{1}$, Alexandru Lupu $^{1}$, Sanaa Brahmia', Mathieu Pioche' ${ }^{1}$

1 Endoscopy and Gastroenterology Unit, Edouard Herriot Hospital, Hospices Civils de Lyon, Lyon, France

2 Gastroenterology and Endoscopy Unit, Dupuytren University Hospital, Limoges, France

\section{Corresponding author}

\section{Mathieu Pioche, MD}

Endoscopy unit - Digestive Disease Department, Pavillon L - Edouard Herriot Hospital, 69437 Lyon Cedex, France Fax: +33-4-72-11-01-47 mathieu.pioche@chu-lyon.fr

\section{References}

[1] Banks PA, Bollen TL, Dervenis C et al. Classification of acute pancreatitis-2012: revision of the Atlanta classification and definitions by international consensus. Gut 2013; 62: 102-111

[2] Bakker OJ, van Santvoort HC, van Brunschot $S$ et al. Endoscopic transgastric vs. surgical necrosectomy for infected necrotizing pancreatitis: a randomized trial. JAMA 2012; 307: 1053-1061

[3] Gardner TB, Coelho-Prabhu N, Gordon SR et al. Direct endoscopic necrosectomy for the treatment of walled-off pancreatic necrosis: results from a multicenter U.S. series. Gastrointest Endosc 2011; 73: 718-726

[4] van der Wiel SE, May A, Poley JW et al. Preliminary report on the safety and utility of a novel automated mechanical endoscopic tissue resection tool for endoscopic necrosectomy: a case series. Endosc Int Open 2020; 8: E274-E280

\section{Bibliography}

Endoscopy 2021; 53: E234-E235

DOI 10.1055/a-1247-4539

ISSN 0013-726X

published online 23.9.2020

(C) 2020. Thieme. All rights reserved.

Georg Thieme Verlag KG, Rüdigerstraße 14,

70469 Stuttgart, Germany

\section{ENDOSCOPY E-VIDEOS}

https:|/eref.thieme.de/e-videos

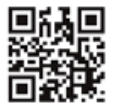

Endoscopy E-Videos is a free access online section, reporting on interesting cases and new

techniques in gastroenterological endoscopy. All papers include a high quality video and all contributions are freely accessible online.

This section has its own submission website at

https://mc.manuscriptcentral.com/e-videos 